\title{
KOMPRESI FILE MENGGUNAKAN KONVERSI BINER HEXADECIMAL DAN ALGORITMA HUFFMAN ENCODING
}

\author{
Karlo Geofandy ${ }^{1}$, Erlando Aubrey N ${ }^{2}$, Halim Agung ${ }^{3}$ \\ Program Studi Teknik Informatika ${ }^{1,2,3}$ \\ Universitas Bunda Mulia \\ Jl. Lodan Raya No 2 Ancol, Jakarta \\ karlogeofandy@gmail.com ${ }^{1}$, erlando.aubrey.nathaniel@gmail.com ${ }^{2}$, hagung@ bundamulia.ac.id $^{3}$
}

\begin{abstract}
Abstrak
Seiring dengan perkembangannya, teknologi data dalam bentuk file terus berkembang dan mengalami peningkatan ukuran dari waktu ke waktu. Perkembangan teknologi yang semakin maju dengan penambahan jumlah pengguna komputer yang semakin banyak menyebabkan ledakan jumlah data serta tingkat perpindahan data dari satu perangkat ke perangkat lain. Data - data tersebut umumnya dikompresi terlebih dahulu agar proses pertukaran data tidak memakan waktu yang terlalu lama. Metode yang akan digunakan pada penelitian ini adalah algoritma Huffman Encoding dan konversi Biner Hexadecimal. algoritma Huffman Encoding adalah salah satu algoritma kompresi dengan cara melakukan pengkodean dalam bentuk bit untuk mewakili data karakter, sedangkan konversi Biner Hexadecimal adalah teknik untuk mengubah rangkaian bit yang akan dikonversi menjadi bilangan hexadecimal. Hasil dari penelitian ini adalah algoritma Huffman Encoding dan konversi Biner Hexadecimal dapat diimplementasikan untuk kompresi file. Simpulan dari aplikasi ini yaitu metode Huffman Encoding dan konversi Biner Hexadecimal dapat melakukan mengkompresi dengan baik pada 26 macam ekstensi file akan tetapi, metode ini tidak lebih baik dibandingkan program kompresi WinRAR dan WinZIP. Ini telah dibuktikan dengan pengujian keterbatasan dan peforma program terhadap 50 jenis file yang berbeda.
\end{abstract}

Kata kunci:

Kompresi, file, Huffman encoding, hexadecimal, biner, server.

\section{Abstract}

Along with its development, data technology in the form of files continues to grow and increase in size over time. The development of increasingly advanced technology by increasing the number of computer users which is increasingly causing an explosion in the amount of data and the rate of data transfer from one device to another. The data is generally compressed first so that the data exchange process does not take too long. The method that will be used in this research is the Huffman Encoding algorithm and Binary Hexadecimal conversion. Huffman Encoding algorithm is a compression algorithm by coding in the form of bits to represent character data, while Hexadecimal Binary conversion is a technique to change the sequence of bits to be converted into hexadecimal numbers. The results of this study are the Huffman Encoding algorithm and Hexadecimal Binary conversion can be implemented for file compression. The conclusion of this application is the Huffman Encoding method and Binary Hexadecimal conversion can compress well on 26 file extensions, however, this method is no better than the WinRAR and WinZIP compression programs. This has been proven by testing the limitations and performance of programs against 50 different file types.

Keywords :

Toll Road, Compression, file, Huffman encoding, hexadecimal, binary, server.

\section{Pendahuluan}

Kompresi adalah kegiatan yang dilakukan untuk mengurangi ukurannya menjadi lebih kecil dari sebelumnya. Kompresi dibuat karena kurangnya kapasitas penyimpanan yang memadai. Kompresi file juga diperlukan untuk mempercepat aktivitas pengiriman data antar jaringan komputer. Kompresi memiliki aturan yang berbeda antara 
kecepatan dan kepadatan (Marlina, Siahaan, Kurniawan, \& Sulistianingsih, 2017).

Seiring dengan perkembangannya, teknologi data dari file-file terus berkembang dan mengalami peningkatan ukuran menjadi semakin besar dari waktu ke waktu. Terdapat berbagai tipe data yang dapat dimuat yakni teks, gambar, audio dan video.

Perkembangan teknologi yang semakin maju dan penambahan jumlah pengguna komputer yang semakin banyak menyebabkan ledakan data serta perpindahan data dari satu perangkat ke perangkat lain. Data-data tersebut umumnya dikompresi terlebih dahulu agar proses pertukaran tidak memakan waktu yang terlalu lama.

Pada penelitian ini, penulis hendak memadukan algoritma Huffman Encoding dengan teknik Biner to Hexadecimal dengan harapan dapat memaksimalkan hasil kompresi.

\section{KAJIAN LITERATUR}

\section{II.1 Sistem Bilangan}

Sistem bilangan secara sederhana didefinisikan sebagai cara mudah berhitung. Bilangan atau sistem perhitungan awal yang digunakan manusia dikembangkan untuk membantu menentukan jumlah harta yang seseorang miliki. Sejak manusia menemukan perlunya menghitung benda-benda, mereka mencari cara termudah untuk berhitung, sekitar tahun 1672 Gottfried Wilhelm von Leibnez menyempurnakan mesin yang dapat melakukan semua operasi dasar (Mutiara \& Handayani, 2015). Mesin ini yang kemudian digunakan pada sistem komputer.

Lain halnya dengan sistem komputer, sistem komputer merupakan sebuah sistem terintegrasi dari beberapa elemen perangkat lunak dan perangkat keras yang dioperasikan oleh pengguna. Pengintegrasian elemen-elemen tersebut tak lepas dari suatu konsep representasi informasi untuk diimplementasikan dan dilibatkan dalam sistem komputer. Representasi informasi dalam sistem komputer berperan sangat penting dalam melakukan pengolahan data dan informasi (Mutiara \& Handayani, 2015). Sistem komputer ini dapat diklasifikasikan sebagai berikut:

1. Bilangan Decimal: Bilangan desimal merupakan bilangan yang direpresentasikan untuk pengguna, dimana pengguna melakukan segala komputasi berdasarkan bilangan desimal. Bilangan desimal berbasis sepuluh menggunakan sepuluh simbol bilangan yaitu: "0", "1", "2", "3", "4", "5", “6", "7", "8" dan "9" (Mutiara \& Handayani, 2015).

2. Bilangan Biner: Bilangan biner merupakan bilangan dasar sistem komputer berbasis dua. Oleh karena itu bilangan biner menggunakan 2 simbol bilangan yaitu, "0" dan"1" (Mutiara \& Handayani, 2015)

3. Bilangan Octal: Bilangan oktal merupakan bilangan yang digunakan komputer untuk representasi eksternal yang bertujuan membatasi panjang string dan mempermudah pengguna membaca representasi bilangan biner melalui bilangan oktal (Mutiara \& Handayani, 2015)

4. Bilangan Hexadecimal: Seperti halnya bilangan oktal, bilangan hexadecimal merupakan bilangan yang digunakan komputer untuk representasi eksternal yang bertujuan membatasi panjang string. Bilangan hexadecimal mempermudah pengguna membaca representasi bilangan biner melalui bilangan hexadecimal. Bilangan heksadesimal memiliki basis enam belas dengan simbol bilangan yang digunakan terdiri dari "0”, "1", "2", "3", “4", "5", “6", "7", "8", "9", "A", "B", "C", "D", "E", dan "F" (Mutiara \& Handayani, 2015)

\section{II.2 Teknik Kompresi}

Sampai saat ini setidaknya ada 2 teknik dalam mengkompresi file, yaitu:

a) Lossy compression: Dalam teknik kompresi Lossy, lossy mengurangi bit dengan mengenali informasi yang tidak diperlukan dan dengan menghilangkan bit tersebut. Dalam metode ini beberapa kerugian informasi dapat diterima. Menghilangkan informasi yang tidak penting dari sumber data dapat menghemat area penyimpanan (Singh, Kumar, Chouhan, \& Shrivastava, 2016)

b) Lossless compression: Dalam teknik kompresi lossless dengan kompresi dari data yang ketika didekompresi, akan menjadi replika yang sama dengan data aktual. Dalam hal ini, ketika data biner seperti dokumen, aplikasi, gambar dll. Kompresi Ini harus direproduksi persis ketika didekompresi lagi. Sebaliknya, gambar dan musik juga tidak perlu dihasilkan tepat. Kemiripan gambar sebenarnya adalah cukup untuk yang paling objektif, sejauh kesalahan atau masalah antara gambar aktual dan gambar terkompresi dapat dihindari atau lumayan (Singh, Kumar, Chouhan, \& Shrivastava, 2016) 


\section{II.3 Teknik Kompresi}

Algoritma merupakan suatu metode khusus yang tepat dan terdiri dari serangkaian langkah yang terstruktur dan dituliskan secara sistematis yang akan dikerjakan untuk menyelesaikan suatu masalah dengan bantuan komputer. Algoritma merupakan suatu prosedur untuk melakukan satu tugas spesifik berupa gagasan dibalik suatu program.

Sebuah algoritma kompresi dapat dievaluasi dalam sejumlah cara yang berbeda. Yang diukur adalah kompleksitas relatif dari algoritma kompresi, memori yang diperlukan untuk melaksanakan algoritma, seberapa cepat algoritma melakukan pada mesin yang diberikan, jumlah kompresi, dan bagaimana erat rekonstruksi menyerupai aslinya, berikut beberapa algoritma lossless compression:

1. Elias Delta Code ditemukan oleh Peter Elias. Kode ini juga menerapkan metode Gamma code, terutama di kepala. Teknik-tekniknya adalah sebagai berikut:

a. Cari peringkat tertinggi dari biner, misalnya desimal 11 jika ditetapkan ke 1011 di mana peringkat tertinggi adalah 3 . Jadi $\mathrm{N}^{\prime}=3$.

b. Gunakan Gamma Coding untuk menyandikan angka $\mathrm{N}$ di mana $\mathrm{N}=\mathrm{N}^{\prime}+1$. Jadi untuk kasus desimal 11 maka kita harus membuat Gamma Coding dari 4 yaitu 00100 .

c. Tambahkan sisa biner $\mathrm{N}^{\prime}$ ke hasil \# 2. Jadi jawabannya adalah 00100011.

Prinsipnya adalah kebalikan dari langkah satu hingga tiga di atas (Hariyanto \& Siahaan, 2018).

2. Huffman Encoding: Algoritma Huffman adalah algoritma yang dikembangkan David A. Huffman pada 1952. Algoritma Huffman menggunakan prinsip pengkodean yang mirip dengan kode morse, yaitu tiap karakter (symbol) dikodekan hanya dengan rangkaian beberapa bit, dimana karakter yang sering muncul dikodekan dengan rangkaian bit yang pendek dan karakter yang jarang muncul dikodekan dengan rangkaian bit yang lebih panjang, karena prosesnya yang menggunakan kode ini, membuat algoritma Huffman sebagai algoritma keluarga dengan variable codeword length (Prayoga \& Suryaningrum, 2018). Cara kerjanya:

a. Menghitung banyaknya jenis karakter dan jumlah dari masing-masing karakter yang terdapat dalam sebuah file. b. Menyusun setiap jenis karakter dengan urutan jenis karakter yang jumlahnya paling sedikit ke yang jumlahnya paling banyak.

c. Membuat pohon biner berdasarkan urutan karakter dari yang jumlahnya terkecil ke yang terbesar, dan memberi kode untuk tiap karakter.

d. Mengganti data yang ada dengan kode bit berdasarkan pohon biner.

e. Menyimpan jumlah bit untuk kode bit yang terbesar, jenis karakter yang diurutkan dari frekuensi keluarnya terbesar ke terkecil beserta data yang sudah berubah menjadi kode bit sebagai data hasil kompresi.

\section{Metodologi Penelitian}

\section{III.1 Perancangan Sistem}

Pada pembangunan sistem akan digunakan model pengembangan waterfall, dikarenakan model pengembangan waterfall melaksanakan proses pembangunan sistemnya secara bertahap dan tidak ada proses dikerjakan secara bersamaan. Berikut adalah tahapan-tahapan yang dilakukan pada perancangan sistem dengan model waterfall:

a) Analisis Kebutuhan

\section{i. Analisis Kebutuhan Fungsional}

1. Sistem dapat membaca binary file dan mengkonversi menjadi bilangan hexadecimal.

2. Sistem dapat melakukan kompresi data terhadap bilangan hexadecimal yang telah dikonversi dengan menggunakan algoritma Huffman Encoding.

3. Sistem dapat mengembalikan data yang telah dikompresi

ii. Analisis Kebutuhan Non Fungsional

Kebutuhan perangkat keras (Hardware) yang diperlukan untuk mengimplementasikan sistem minimal memiliki spesifikasi sebagai berikut:

1. Processor min. intel core i5 inside $7200 \mathrm{U}$

2. Memori : $8 \mathrm{~GB}$

3. Sistem Operasi: Microsoft Windows

b) Desain Sistem 
Pada tahapan desain sistem, dirancang bagaimana tampilan antarmuka dari sistem atau aplikasi agar mudah digunakan oleh user. Tidak hanya desain antar muka yang dirancang, diagram - diagram yang menggambarkan bagaimana sistem bekerja dan berinteraksi dengan user juga dirancang pada tahapan desain sistem berupa use case diagram dan activity diagram

c) Penulisan Kode Program

Bahasa pemrograman yang digunakan dalam merancang/membangun aplikasi adalah bahasa pemrograman Javascript yang berjalan pada server Node.js. Aplikasi yang digunakan untuk menulis kode program adalah Visual Studio Code. Untuk menjalankan aplikasi menggunakan browser.

d) Kompresi

Kompresi dilakukan dengan mengombinasikan algoritma Huffman Encoding yang digunakan untuk melakukan kompresi data dengan cara tiap karakter (simbol) dikodekan hanya dengan rangkaian beberapa bit, dimana karakter yang sering muncul dikodekan dengan rangkaian bit yang pendek dan karakter yang jarang muncul dikodekan dengan rangkaian bit yang lebih panjang dan teknik Biner to Hexadecimal untuk mengubah rangkaian bit yang akan dikonversi menjadi bilangan hexadecimal, dimana hexadecimal memiliki panjang bit yang lebih sedikit

e) Dekompresi

File yang telah berhasil dikompresi akan disimpan menjadi file lain dengan ekstensi yang baru, untuk menggunakannya file harus terlebih dahulu didekompresi dengan menggunakan algoritma Huffman Encoding dan mengembalikan data hexadecimal menjadi binary kembali

\section{II.1 Perancangan Proses}

a) Flowchart Diagram

Flowchart Diagram pada gambar 1.a menjelaskan alur proses saat melakukan pengkompresian. Berikut merupakan penjelasannya:

1. User mengunggah file yang telah dipilih,

2. Program membaca data binary dari file dan diubah menjadi data hexadecimal.

3. Data hexadecimal tersebut akan dikompresi menggunakan Huffman Encoding

4. Data disimpan pada server.
Flowchart Diagram pada gambar 1.b menjelaskan alur proses saat melakukan pengdekompresian. Berikut merupakan penjelasannya:

1. User memilih file yang akan didekompres,

2. File akan didekompres menggunakan Huffman Encoding.

3. Data dikembalikan menjadi binary file

4. file siap untuk diunduh.

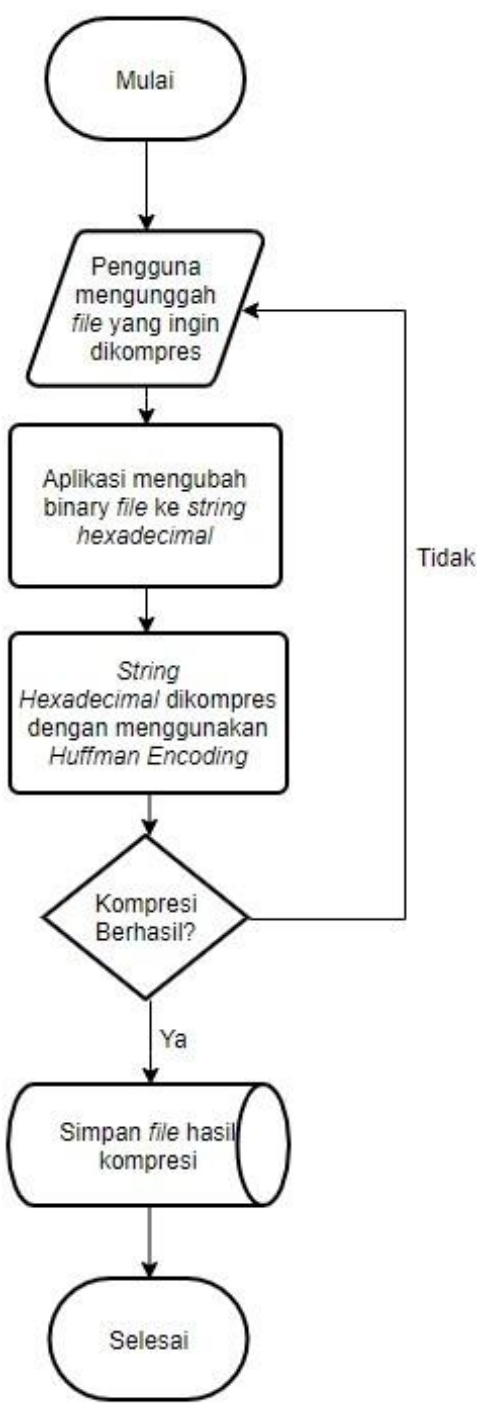

Gambar 1 Flowchart alur sistem kompresi 


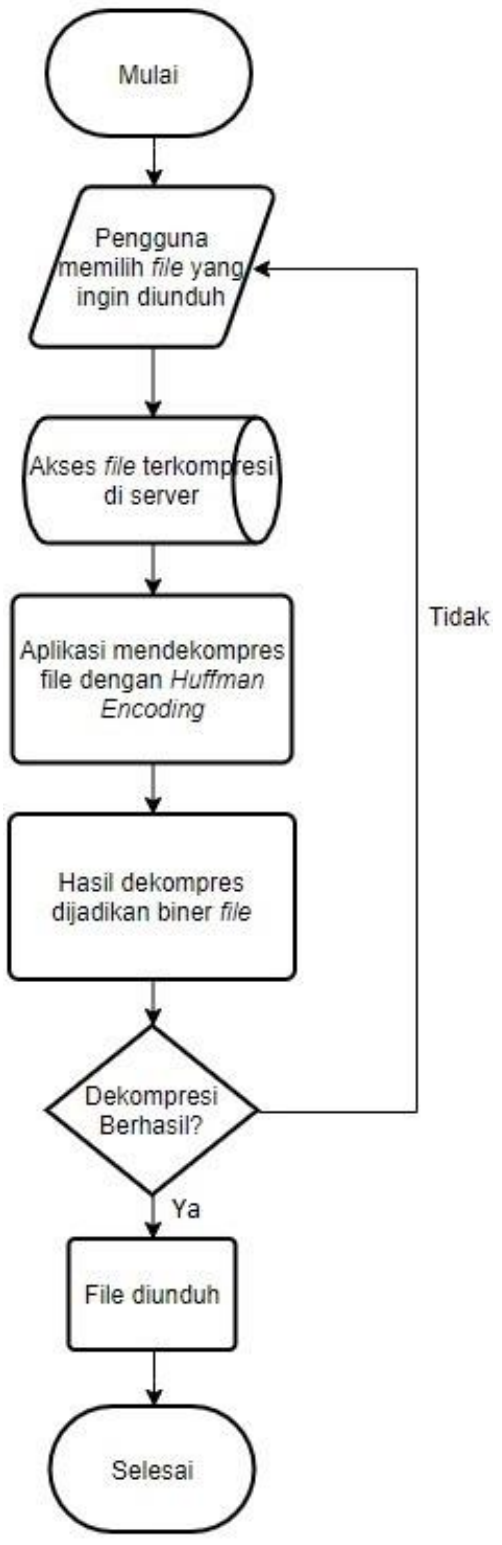

Gambar 2 Flowchart alur sistem dekompresi

\section{a) Data Flow Diagram}

Pada gambar 3 menjelaskan Data Flow Diagram level 0 , Berikut merupakan penjelasannya:

1. User mengunggah file yang akan dikompres ke sistem.

2. Program menyimpan hasil kompresi.

3. User mengirimkan permintaan untuk mengunduh file
4. Program melakukan dekompresi file yang diminta user.

5. File dikirimkan kembali ke pengguna.

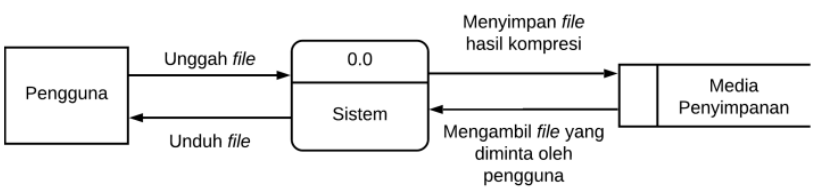

Gambar 3 Data Flow Diagram level 0

Data flow diagram level 1 pada gambar 4 menjelaskan proses dalam sistem yang dibagi menjadi 2 proses, yaitu konversi biner hexadecimal dan Huffman Encoding. Berikut merupakan penjelasan proses kompresi:

1. Untuk mengkompresi File yang diunggah, data binary pada file dikonversi menjadi hexadecimal.

2. File dikompresi menggunakan Huffman Encoding.

3. Sistem menyimpan key dan data ke media penyimpanan.

Proses dekompresi dijelaskan sebagai berikut:

1. Untuk mendekompresi File yang sudah tersimpan, dilakukan Huffman Decoding sesuai dengan key dan data yang sudah disimpan.

2. Hasil dekompresi dibangun kembali filenya dari hexadecimal.

3. Hasil Huffman Decoding kemudian dikirimkan ke user.

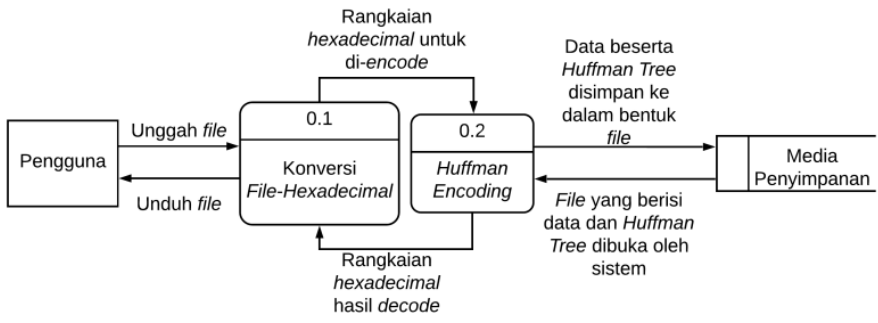

\section{Gambar 4 Data Flow Diagram level 1}

Pada gambar 5, Data Flow Diagram level 2 digambarkan lebih ringkas. Berikut penjelasan dari saat mengkompresi:

1. Biner file dibaca,

2. Setiap 4 bit dari file, diubah ke dalam bentuk hexadecimal.

3. Dilakukan pembuatan Huffman Tree untuk dijadikan key dari Huffman Encoding yang akan dilakukan dan Huffman Decoding nantinya, 
4. Key dan data disimpan menjadi 1 file ke dalam media penyimpanan.

Untuk proses dekompresi, dijelaskan sebagai berikut:

1. File yang sudah tersimpan di media penyimpanan, dipecah menjadi kunci dan data.

2. Data diproses menggunakan Huffman Decoding yang menghasilkan serangkaian hexadecimal.

3. Setelah itu serangkaian tersebut dibuat menjadi file yang kemudian dikirimkan ke pengguna yang memintanya.

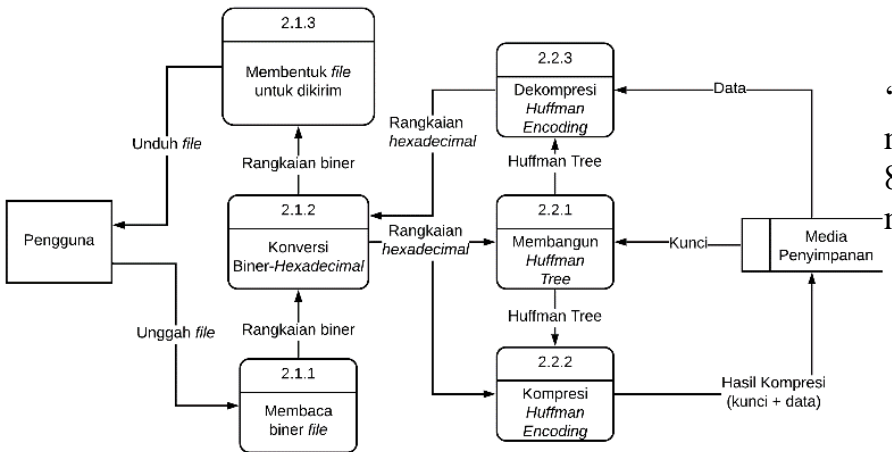

Gambar 5 Data Flow Diagram level 2

\section{III.2 Tampilan Antarmuka}

Ketika user menjalankan program, program akan menampilkan halaman awal seperti yang terlihat pada Gambar 6. Pada tampilan halaman awal, user akan memilih antara melakukan compress files atau decompress files.
Pada halaman compress, user akan memilih file yang akan dikompres seperti yang terlihat pada Gambar 7. Pada tampilan, tombol 'Browse' digunakan untuk memilih file yang akan dikompres, setelah file telah dipilih. Tekan tombol 'Upload' untuk memulai kompresi.

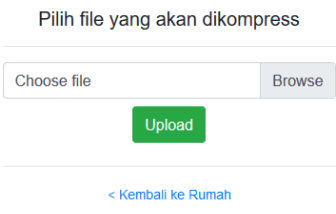

\section{Gambar 7 Antarmuka Halaman Kompres}

File yang berhasil dikompres akan disimpan pada folder 'upload' dengan ekstensi .hxhf dan program akan menampilkan rincian kompresi seperti terlihat pada Gambar 8. Tombol "Klik di sini untuk mendekompres file" akan mengarahkan user ke halaman decompress.

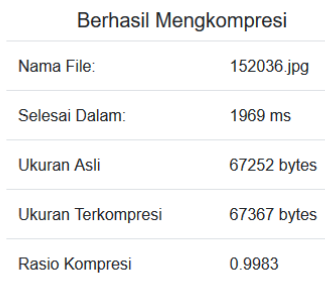

Klik di sini untuk mendekompres file

$<$ Kembali ke Rumah

\section{Gambar 8 Antarmuka Halaman Rincian Kompres}

Pada halaman dekompres, user dapat melihat daftar file yang telah berhasil dikompres sebelumnya seperti terlihat pada Gambar 9. User juga dapat mendekompres file itu kembali ke bentuk awal seperti sebelum dikompresi dengan menekan nama file yang berwarna biru

Mau Apa?

Compress Files Decompress Files

Kompresi files menggunakan Huffman Encoding dan Biner to Hexadecimal.

Dibuat oleh. Ellanoo Aubrey Nantantil 32160060 \& Kanlo Geofandy -32160097

Gambar 6 Antarmuka Halaman Awal

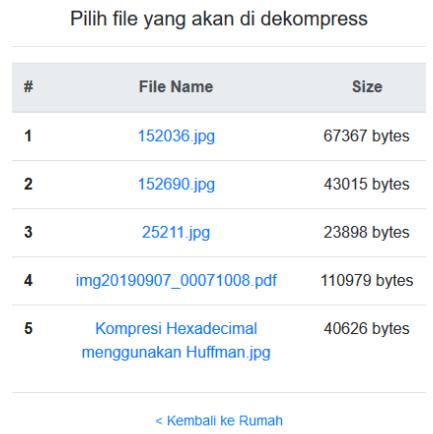

Gambar 9 Antarmuka Halaman Dekompres 
IV. Analisis dan Perancangan

Tabel 1 Analisa Keterbatasan Program

\begin{tabular}{|c|c|c|c|c|}
\hline No & $\begin{array}{c}\text { Ukuran File Eksten } \\
(\text { Byte }) \\
\text { si }\end{array}$ & $\begin{array}{r}\text { Waktu } \\
\text { Kompres } \\
\mathrm{i}(\mathrm{Ms}) \\
\end{array}$ & $\begin{array}{r}\text { Ukuran } \\
\text { Kompresi } \\
(\text { Byte }) \\
\end{array}$ & Hasil \\
\hline 1 & 31.222.057 .ai & 0 & 0 & GAGAL \\
\hline 2 & 226.918 .ai & 8.646 & 224.445 & BERHASIL \\
\hline 3 & 98.622.667 .psd & 0 & 0 & GAGAL \\
\hline 4 & 7.976 .792 .exe & 0 & 0 & GAGAL \\
\hline 5 & 409.600 .exe & 7.913 & 379.807 & BERHASIL \\
\hline 6 & 524.288 .bin & 9.109 & 419.777 & BERHASIL \\
\hline 7 & 118.128 .css & 3.213 & 105.041 & BERHASIL \\
\hline 8 & 769.568 .dat & 21.970 & 769.706 & BERHASIL \\
\hline 9 & $30.740 . \mathrm{html}$ & 781 & 25.525 & BERHASIL \\
\hline 10 & 4.662 .html & 321 & 4.357 & BERHASIL \\
\hline 11 & 353.118 .ico & 6.732 & 254.475 & BERHASIL \\
\hline 12 & 3.027 .933 .jpg & 84.823 & 3.028 .079 & BERHASIL \\
\hline 13 & 143.573 .jpg & 5.575 & 143.703 & BERHASIL \\
\hline 14 & 11.226 .jpg & 445 & 11.340 & BERHASIL \\
\hline 15 & 262.152 .json & 8.812 & 202.709 & BERHASIL \\
\hline 16 & 479 .key & 23 & 438 & BERHASIL \\
\hline 17 & 7.972 .xlsx & 310 & 7.252 & BERHASIL \\
\hline 18 & 19.612 .xlsx & 765 & 19.345 & BERHASIL \\
\hline 19 & 2.570.322 .pptx & 84.938 & 2.570 .468 & BERHASIL \\
\hline 20 & 2.066 .191 .pptx & 38.137 & 2.057 .184 & BERHASIL \\
\hline 21 & 1.492.306 .docx & 25.002 & 1.492 .452 & BERHASIL \\
\hline 22 & 17.442.472.docx & 390.723 & 17.442 .634 & BERHASIL \\
\hline 23 & 150.697 .docx & 2.978 & 150.827 & BERHASIL \\
\hline 24 & $91.082 .298 . \mathrm{mkv}$ & - & - & GAGAL \\
\hline 25 & 17.426.531 .mkv & 353.179 & 17.426 .693 & BERHASIL \\
\hline
\end{tabular}

\begin{tabular}{|c|c|c|c|c|}
\hline No & $\begin{array}{c}\text { Ukuran File Eksten } \\
(\text { Byte }) \text { si }\end{array}$ & $\begin{array}{r}\text { Waktu } \\
\text { Kompres } \\
\mathrm{i}(\mathrm{Ms})\end{array}$ & $\begin{array}{r}\text { Ukuran } \\
\text { Kompresi } \\
(\text { Byte })\end{array}$ & Hasil \\
\hline 26 & 7.469.755 .mp3 & 135.766 & 7.469 .903 & BERHASIL \\
\hline 27 & $3.256 .320 \quad . \mathrm{mp} 3$ & 56.620 & 3.256 .466 & BERHASIL \\
\hline 28 & 3.000.253 .mp4 & 53.807 & 3.000 .399 & BERHASIL \\
\hline 29 & 19.195.672 .mp4 & 463.835 & 19.195 .834 & BERHASIL \\
\hline 30 & 1.100 .260 .apk & 19.327 & 1.100 .406 & BERHASIL \\
\hline 31 & 50.206.216 .apk & - & - & GAGAL \\
\hline 32 & 13.648 .otf & 295 & 12.963 & BERHASIL \\
\hline 33 & $6.555 .683 . \mathrm{pdf}$ & 133.681 & 6.491 .434 & BERHASIL \\
\hline 34 & 105.058 .pdf & 1.817 & 99.523 & BERHASIL \\
\hline 35 & $6.058 .918 . \mathrm{pdf}$ & 117.713 & 6.059 .064 & BERHASIL \\
\hline 36 & 610.359 .pdf & 11.510 & 610.489 & BERHASIL \\
\hline 37 & 77.444 .pkt & 1.331 & 77.558 & BERHASIL \\
\hline 38 & 6.197.404 .png & 122.657 & 6.197 .550 & BERHASIL \\
\hline 39 & 519 .png & 29 & 576 & BERHASIL \\
\hline 40 & 10.578 .png & 198 & 10.692 & BERHASIL \\
\hline 41 & $1.462 . \mathrm{txt}$ & 76 & 1.346 & BERHASIL \\
\hline 42 & 100.494 .txt & 2.120 & 83.920 & BERHASIL \\
\hline 43 & 349.680 .ttf & 7.475 & 286.298 & BERHASIL \\
\hline 44 & $144.156 . \mathrm{ttf}$ & 2.864 & 121.384 & BERHASIL \\
\hline 45 & 24.846.336 .msi & - & - & GAGAL \\
\hline 46 & 11.336.116 .zip & 202.468 & 11.336 .278 & BERHASIL \\
\hline 47 & 77.615 .zip & 1.264 & 77.729 & BERHASIL \\
\hline 48 & 5.939 .144 .zip & 101.448 & 5.939 .290 & BERHASIL \\
\hline 49 & 52.914 .928 .exe & - & - & GAGAL \\
\hline 50 & 50.240 .docx & 910 & 49.974 & BERHASIL \\
\hline
\end{tabular}


Tabel 2 Analisa Peforma Program

\begin{tabular}{|c|c|c|c|c|c|}
\hline No & Ukuran File (Byte) Ekstensi & Hasil ZIP & Hasil RAR & Hasil Program & Kesimpulan \\
\hline 1 & 46.200 docx & 43.768 & 43.632 & 46.315 & LEBIH BESAR \\
\hline 2 & 226.918 .ai & 172.974 & 170.973 & 224.445 & LEBIH BESAR \\
\hline 3 & 409.600 .exe & 212.725 & 171.341 & 379.807 & LEBIH BESAR \\
\hline 4 & $524.288 . \mathrm{BIN}$ & 240.493 & 219.983 & 419.777 & LEBIH BESAR \\
\hline 5 & $118.128 . c s s$ & 16.920 & 15.758 & 105.041 & LEBIH BESAR \\
\hline 6 & 769.568 .dat & 769.848 & 361.276 & 769.706 & LEBIH BESAR \\
\hline 7 & 30.740 .html & 3.640 & 3.517 & 25.525 & LEBIH BESAR \\
\hline 8 & $4.662 . \mathrm{html}$ & 1.510 & 1.433 & 4.357 & LEBIH BESAR \\
\hline 9 & 353.118 .ico & 41.160 & 52.047 & 254.475 & LEBIH BESAR \\
\hline 10 & 3.027 .933 .jpg & 2.990 .660 & 2.978 .472 & 3.028 .079 & LEBIH BESAR \\
\hline 11 & $143.573 \quad . j p g$ & 142.261 & 142.521 & 143.703 & LEBIH BESAR \\
\hline 12 & 11.226 .jpg & 10.712 & 10.642 & 11.340 & LEBIH BESAR \\
\hline 13 & 262.152 .json & 41.263 & 35.808 & 202.709 & LEBIH BESAR \\
\hline 14 & 479 .key & 479 & 435 & 438 & LEBIH BESAR \\
\hline 15 & $7.972 . x 1 s x$ & 5.665 & 5.602 & 7.252 & LEBIH BESAR \\
\hline 16 & 19.612 .xlsx & 14.947 & 14.808 & 19.345 & LEBIH BESAR \\
\hline 17 & 2.570 .322 .pptx & 2.402 .444 & 2.391 .147 & 2.570 .468 & LEBIH BESAR \\
\hline 18 & 2.066 .191 .pptx & 1.682 .387 & 1.649 .032 & 2.057 .184 & LEBIH BESAR \\
\hline 19 & 1.492 .306 .docx & 1.452 .944 & 1.453 .130 & 1.492 .452 & LEBIH BESAR \\
\hline 20 & $17.442 .472 . \operatorname{doc} x$ & 16.913 .122 & 16.461 .875 & 17.442 .634 & LEBIH BESAR \\
\hline 21 & 150.697 .docx & 145.434 & 145.404 & 150.827 & $\begin{array}{l}\text { LEBIH BESAR } \\
\end{array}$ \\
\hline 22 & 17.426.531 .mkv & 17.375 .319 & 17.363 .324 & 17.426 .693 & LEBIH BESAR \\
\hline 23 & $7.469 .755 . \mathrm{mp} 3$ & 7.451 .667 & 7.464 .444 & 7.469 .903 & LEBIH BESAR \\
\hline 24 & $3.256 .320 . \mathrm{mp} 3$ & 3.225 .424 & 3.224 .395 & 3.256 .466 & LEBIH BESAR \\
\hline 25 & $3.000 .253 . \mathrm{mp} 4$ & 2.962 .204 & 2.958 .646 & 3.000 .399 & LEBIH BESAR \\
\hline 26 & 19.195.672 .mp4 & 19.065 .616 & 19.078 .921 & 19.195 .834 & LEBIH BESAR \\
\hline
\end{tabular}

Karlo Geofandy, Erlando Aubrey N, Halim Agung 


\begin{tabular}{|c|c|c|c|c|c|}
\hline No & Ukuran File (Byte) Ekstensi & Hasil ZIP & Hasil RAR & Hasil Program & Kesimpulan \\
\hline 27 & 1.100.260 .apk & 1.090 .806 & 1.092 .059 & 1.100 .406 & LEBIH BESAR \\
\hline 28 & 13.648 .otf & 10.043 & 9.770 & 12.963 & LEBIH BESAR \\
\hline 29 & $6.555 .683 . \mathrm{pdf}$ & 5.059 .007 & 4.875 .768 & 6.491 .434 & LEBIH BESAR \\
\hline 30 & $105.058 . \mathrm{pdf}$ & 60.579 & 60.490 & 99.523 & LEBIH BESAR \\
\hline 31 & 6.058 .918 .pdf & 5.459 .131 & 5.433 .677 & 6.059 .064 & LEBIH BESAR \\
\hline 32 & 610.359 .pdf & 599.450 & 599.605 & 610.489 & LEBIH BESAR \\
\hline 33 & 77.444 .pkt & 77.625 & 77.519 & 77.558 & LEBIH BESAR \\
\hline 34 & 6.197.404.png & 6.198 .491 & 6.197 .579 & 6.197 .550 & LEBIH KECIL \\
\hline 35 & 519 .png & 630 & 587 & 576 & LEBIH KECIL \\
\hline 36 & 10.578 .png & 10.739 & 10.648 & 10.692 & LEBIH BESAR \\
\hline 37 & 1.462 .txt & 893 & 840 & 1.346 & LEBIH BESAR \\
\hline 38 & 100.494 .txt & 26.095 & 25.619 & 83.920 & LEBIH BESAR \\
\hline 39 & $349.680 . \mathrm{ttf}$ & 153.794 & 101.598 & 286.298 & LEBIH BESAR \\
\hline 40 & $144.156 . \mathrm{ttf}$ & 66.199 & 63.319 & 121.384 & LEBIH BESAR \\
\hline 41 & 11.336.116 .zip & 11.334 .111 & 11.336 .374 & 11.336 .278 & LEBIH BESAR \\
\hline 42 & 77.615 .zip & 77.796 & 77.690 & 77.729 & LEBIH BESAR \\
\hline 43 & 5.939 .144 .zip & 5.929 .047 & 5.939 .361 & 5.939 .290 & LEBIH BESAR \\
\hline 44 & 50.240 .docx & 44.815 & 44.716 & 49.974 & LEBIH BESAR \\
\hline 45 & 109.505 .png & 109.244 & 109.105 & 109.635 & LEBIH BESAR \\
\hline 46 & $1.537 . \mathrm{txt}$ & 472 & 397 & 1.340 & LEBIH BESAR \\
\hline 47 & 4.976.165 .pdf & 4.576 .439 & 4.550 .148 & 4.976 .311 & LEBIH BESAR \\
\hline 48 & 46.200 .docx & 43.768 & 43.632 & 46.315 & LEBIH BESAR \\
\hline 49 & $1.404 . \mathrm{txt}$ & 364 & 288 & 736 & LEBIH BESAR \\
\hline 50 & 3.359 .542 .txt & 1.221 .450 & 1.014 .672 & 2.879 .426 & LEBIH BESAR \\
\hline
\end{tabular}

Karlo Geofandy, Erlando Aubrey N, Halim Agung 


\section{KESIMPULAN}

Memuat beberapa kesimpulan penting dari hasil penelitian dan mencantumkan saran untuk perbaikan penelitian berikutnya.

Referensi dituliskan menggunakan style APA fifth edition, yaitu Nama penulis, tahun, judul, sumber [jurnal, prosiding, bagian buku, artikel dari internet dan lain-lain.

Referensi ditampilkan sesuai urutan pencantuman pada artikel, bukan berdasarkan alphabet penulis.

\section{REFERENSI}

Afyenni, R. (2014). Perancangan Data Flow Diagram Untuk Sistem Informasi Sekolah (Studi Kasus Pada SMA Pembangunan Laboratorium UNP). Jurnal TEKNOIF, 2(1), 35-39.

Ardiyanto, D., \& Purwoto, B. H. (2014). Kompresi Citra dengan Menggunakan Metode Delta Modulation. Jurnal Emittor, 14(1), 1-12.

Chulkamdi, M. T., Pramono, S. H., \& Yudaningtyas, E. (2015, Juni). Kompresi Teks Menggunakan Algoritma Huffman dan Md5 pada Instant Messaging Smartphone Android. Jurnal EECCIS, 9(1), 103-108.

Dennis, A., Wixom, B. H., \& Tegarden, D. (2015). Systems Analysis and Design (Vol. 5). New York: Wiley.

Hariyanto, E., \& Siahaan, A. P. (2018). Design of Adaptive Compression Algorithm Elias Delta Code and Huffman. International Journal For Innovative Research In Multidisciplinary Field, 4(10), 78-87.

Hidayat, T., Zakaria, M. H., \& Pee, A. C. (2018, December). Comparison of Lossless Compression Schemes for WAV Audio Data 16-Bit between Huffman and Coding Arithmetic. International Journal of Simulation Systems, Schience \& Technology, 19(6), 36.1-36.7.

Jambek, A. B., \& Khairi, N. A. (2014). Performance Comparison of Huffman and Lempel-Ziv Welch Data Compression for Wireless
Sensor Node Application. American Journal of Applied Sciences, 11(1), 119-126.

Kaur, S., \& Singh, S. (2016). Entropy Coding and Different Coding Techniques. Journal of Network Communications and Emerging Technologies (JNCET), 6(5), 4-7.

Krasmala, R., Purba, A. B., \& Lenggana, U. (2017, Juni). Kompresi Citra dengan MenggabungkanMetode Discrete Cosine Transform (DCT) dan Algoritma Huffman. Jurnal Online Informatika, 2(1-9), 1.

Marlina, L., Siahaan, A. P., Kurniawan, H., \& Sulistianingsih, I. (2017). Data Compression Using Elias Delta Code. International Journal of Recent Trends in Engineering \& Research, 3(8), 210-217.

Marzuki, I. (2017). Aplikasi Kompresi Untuk Pengiriman Data Menggunakan Metode LZW (Lemple Ziv Welch). Energy, 7(2), 3843.

Muslihudin, M., \& Oktafianto. (2016). Analisis dan Perancangan Sistem Informasi Menggunakan Model Terstruktur dan UML. Yogyakarta: Penerbit Andi.

Mutiara, G. A., \& Handayani, R. (2015). Sistem Komputer Representasi Data. Sleman: Deepublish.

Prayoga, E., \& Suryaningrum, K. M. (2018). Implementasi Algoritma Huffman Dan Run Length Encoding Pada Kompresi Berbasis Web. Jurnal Ilmiah Teknologi Informasi Terapan, 14(1), 92-101.

Purwaningsih, F., \& Badrul, M. (2017). Penerapan Algoritma Huffman Untuk Aplikasi Pengamanan Sms Berbasis Android. Jurnal PROSISKO, 4(2), 60-66.

Raharja, B. D., \& Harsadi, P. (2018). Implementasi Kompresi Citra Digital Dengan Mengatur Kualitas Citra Digital. Jurnal Ilmiah SINUS (JIS), 16(2), 71-77.

Santoso, \& Nurmalina, R. (2017). Perencanaan dan Pengembangan Aplikasi Absensi Mahasiswa Menggunakan Smart Card Guna Pengembangan Kampus Cerdas (Studi Kasus Politeknik Negeri Tanah Laut). Jurnal Integrasi, 9(1), 84-91. 
Singh, M., Kumar, S., Chouhan, S. S., \& Shrivastava, M. (2016). Various Image Compression Techniques: Lossy and Lossless. International Journal of Computer Applications, 142(6), 23-26.

Sitorus, L. (2015). Algoritma dan pemrograman. Yogyakarta: Penerbit Andi.

Yana, G. I., \& Hondro, R. K. (2016, Desember). Implementasi Algoritma Huffman dan LZ78 untuk Kompresi Data. Jurnal Riset Komputer (JURIKOM), 3(6), 42-44.

Yaragunti, H. S., \& Reddy, T. (2015, December). Text Based Image Compression Using Hexadecimal Conversion. Oriental Journal of Computer Science \& Technology, 8(3), 216-221. 